\title{
The Influence of Agroclimatic Factors on the Formation of Oil Content in Flax Seeds in the North of Kazakhstan
}

\author{
Yelena Gordeyeva $^{1 *}$, Nina Shestakova ${ }^{1}$ \\ 1 S. Seifullin Kazakh Agrotechnical University, Zhenis Avenue, 62, 010011, Astana, Kazakhstan \\ * Corresponding author's e-mail: gordeeva1311@mail.ru
}

\begin{abstract}
Flax (Linum usitatissimum L.) is one of the promising oil crops in the north of Kazakhstan. Over the last 10 years, the total area under this crop in the region has increased fourteen-fold, since flax is a very plastic crop for steppe and dry steppe conditions, and oil seeds are in high demand in the world market. Flaxseed oil, due to the content of polyunsaturated fatty acids, occupies one of the first positions among other edible vegetable oils. Depending on the environmental conditions, the oil content of the crop may vary from $36.4 \%$ to $52.0 \%$, while, as noted by many researchers, the change in the oil content depends on the genotypic characteristics. Therefore, the study aims to analyze the influence of the genotype and climatic conditions of cultivation on the fat biosynthesis in flax seeds in the context of the dry steppe zone of Northern Kazakhstan on dark chestnut soils of the Akmola region. Field experiments were conducted in 2015-2017 with the study of nine oil flaxseed cultivars (of mid-season varieties) sown on May 20th at the seeding rate of 7 million seeds/ha based on the traditional technology of cultivation recommended for the region. The climatic parameters were taken into account according to the meteorological service data. The fat content was determined by the extraction method using a Soxhlet apparatus, in accordance with GOST (AllUnion State Standard) 10857-64, and the moisture content was determined by means of the thermogravimetric method, according to the National Standard of the Republic of Kazakhstan 2.195-2010, for the recalculation of the oil content for absolutely dry matter. It was found that the formation of oil depends on the climatic parameters and on the sum of active temperatures during the ripening period, in particular. The evaluation of plasticity and stability of the cultivars (genotypes) showed that VNIIMK 620, Lirina, Karabalyksky 7 can be considered highly valuable cultivars and Severny, Biryuza, Kazar, Ilyich - valuable cultivars in terms of the oil content for the dry steppe zone.
\end{abstract}

Keywords: oil flax, fat biosynthesis, genotype, plasticity, stability, climatic parameters.

\section{INTRODUCTION}

Flax (Linum usitatissimum L.) is one of the promising agricultural crops, the seeds of which are widely used for food, technical and medical purposes. Flaxseed oil, due to the high content of polyunsaturated fatty acids (PUFA), occupies one of the first positions among other edible vegetable oils [Brazhnikov, 2004; Brazhnikov and Brazhnikova 2013]. Flax seeds contain 30-50\% of fatty oil, which includes glycerides of linolenic (30-60\%), linoleic (17-35\%), oleic (15-20\%), palmitic (5-7\%) and stearic (3-4\%) acids; $12-26 \%$ of protein, organic acids, enzymes, vitamins, and styrenes. The polyfunctionality of this crop determines its distribution across the world [Zuk et al. 2015].
Depending on the environmental conditions, the oil content of the crop may vary from $36.4 \%$ to $52.0 \%$. Sharp temperature fluctuations during the ripening period cause a relatively greater accumulation of unsaturated fatty acids. Many researchers note that the change in oil content depends on the genotypic differences [Kumar et al. 2015; Krasnova 2010; Galitsky and Shamanin 2014]. Kumar et al. [2015] show genetic markers determining the formation of the fatty acid composition of oil and total oil. According to Krasnova [2010], the difference in the content of raw fat among flaxseed cultivars varied from $18 \%$ to $43 \%$. Galitsky and Shamanin [2014] note the range of variation not only within the genotype, but also with regard to the climatic conditions of cultivation. This is also confirmed by the study of 
198 oil flaxseed cultivars in the Ethiopian center [Worku et al. 2015].

The influence of various agricultural practices on the change in the oil content is considered by many authors both within the CIS and abroad [Antonova and Gerlets 2012; Kuznetsova 2004; Magomedov et al. 2008; Bushnev et al. 2009; Cherenkov 2009; Andruszczak et al. 2015]. Safonov's studies [Safonov, 1952] revealed that late ripeness is combined with greater oil content. At the same time, some other studies [Magomedov et al. 2008; Bushnev et al., 2009] established an average dependence between the duration of the growing season as a whole and the oil content. O.A. Cherenkov also confirms these data [Cherenkov 2009]. Certain contradictions found in research indicate the need for further study of the relationship between the characteristics of flax in a particular region and their effect on the accumulation of oil.

The aim of this paper was to study the relationship between the genotype of flax, the conditions of its cultivation in a particular region and their influence on fat biosynthesis in seeds.

\section{MATERIALS AND METHODS}

The experiments were conducted under the dry steppe conditions of the Akmola region in 2015-2017 to study the influence of genotypes and various agricultural practices on fat biosynthesis in flax seeds. Field experiments were carried out with the method of the State Network of Cultivars of the Republic of Kazakhstan (2011) on dark chestnut soils of the Akmola region.

The experimental scheme included the study of nine flax cultivars of different breeding, namely Severny, Isilkulsky (Isilkul Experimental Station of All-Russia Research Institute of Oil Crops, Russia), VNIIMK 620, Biryuza (All-Russia Research Institute of Oil Crops by V.S. Pustovoit, Krasnodar, Russia), Lirina (Romania), Kostanay amber, Kazar, Ilyich (Northwestern Agricultural Research Institute of the Republic of Kazakhstan), and Karabalyksky 7 (Karabalyk Experi- mental Station of the Republic of Kazakhstan). The experiments were repeated four times, with the accounting area of the plot being $25 \mathrm{~m}^{2}$.

The adaptive properties of oil formation in seeds were evaluated by the method proposed by Eberhart and. Russell described by Zyk et al. [2015]. This method is based on calculating two parameters: the linear regression coefficient and the coefficient of standard deviation from the regression line - dispersion. The regression coefficient gives an estimate of plasticity of the cultivar (by oil accumulation) in the genetic sense. The second coefficient characterizes the stability of the cultivar under various environmental conditions. The fat content in seeds was determined in an accredited laboratory of biochemistry and the quality selection of "A.I. Baraev Scientific and Production Center of Grain Farming" LLP by the extraction method using a Soxhlet apparatus in accordance with GOST (All-Union State Standard) 10857-64 "Oilseeds. Method for determination of oil content". The moisture content was determined by the thermogravimetric method according to the National Standard of the Republic of Kazakhstan 2.195-2010, for recalculation of oil content for absolutely dry matter.

\section{RESULTS AND DISCUSSION}

The climatic conditions during the experimental period were characterized by considerable unevenness, both in the temperature regime and in the amount of precipitation. These conditions can be estimated by an index of the hydrothermal coefficient, both for the entire growing period and for individual periods: sprouting-flowering, flowering-ripening (Table 1), which is especially important for the formation of technological qualities of seeds.

The data on the climatic parameters show that each year of the study can be characterized as dry. However, to estimate the intensity of atmospheric droughts, Zoidze [2004] proposed that Selyaninov's hydrothermal coefficient (HTC) should be estimated in five categories of the intensity of

Table 1. Estimation of climatic parameters during the growing period of oil flax

\begin{tabular}{|c|c|c|c|c|}
\hline Year & Sprouting-flowering & Flowering-ripening & Sprouting-ripening & $\begin{array}{c}\text { Estimation for the flowering- } \\
\text { ripening period }\end{array}$ \\
\hline 2015 & 0.70 & 0.26 & 0.49 & dry \\
\hline 2016 & 2.30 & 0.21 & 1.04 & dry \\
\hline 2017 & 0.12 & 0 & 0.08 & very dry \\
\hline
\end{tabular}


atmospheric droughts: very strong (HTC $<0.19)$, strong ( $\mathrm{HTC}=0.20-0.39)$, average ( $\mathrm{HTC}=$ $0.40-0.60)$, weak $(\mathrm{HTC}=0.61-0.75)$, and without droughts (HTC <0.75) [Safonov 1952; Galkin and Sorochinskaya 1984]. Therefore, it should be noted that the sprouting-flowering period was characterized as a period of weak droughts or their absence in 2015-2016, at the same time, the year 2017 was characterized by a very strong drought. The second growing period in all years of the study was affected by a very strong and strong drought (Table 1).

The average oil content of flax seeds in all years of the study varies from $42.9 \%$ to $48.8 \%$. The difference between the individual cultivars by this indicator within a year is $3.2-5.1 \%$. At the same time, the variation of oil content in terms of climatic parameters is less significant within a single cultivar and can reach $0.5-4.4 \%$ with an average value of $2.2 \%$ (Table 2 ).

While analyzing the effect of the sum of temperatures during the ripening period in each year of the study, it was found that the ripening of the cultivars in 2016 took place at a reduced temperature $\left(315^{\circ} \mathrm{C}\right)$ and extended vegetation to $97-100$ days, which could not but affect the accumulation of oil in seeds (compared with $2015-402^{\circ} \mathrm{C}$ and $2017-438^{\circ} \mathrm{C}$ ). Consequently, it is possible to establish a limiting range of variation of oil content, which accounts for the sum of temperatures over this period from $300^{\circ} \mathrm{C}$ to $450^{\circ} \mathrm{C}$. The optimum sum of temperatures for ripening in drought conditions should be $350-400^{\circ} \mathrm{C}$.

The maximum oil content in all years of the study was noted in the cultivars Biryuza, VNIIMK 620, Lirina and Karabalyksky 7 (higher than the average for the cultivars). In order to study the role of the genotype and the environment in the variability of oil content in oil flax seeds, the linear regression coefficient (bi) was calculated. For this purpose, the index of environmental conditions (Ij) was determined. The year 2015 had the most favorable climatic conditions for the formation of oil content, with the index of environmental conditions being 1.4, while the worst conditions were observed in $2017(\mathrm{Ij}=-0.8)$.

The corresponding calculations show that the most valuable are the cultivars, the oil content of which is average or high, the regression coefficient (bi) is close to 1 or more and stability $\left(\sigma_{\mathrm{d} 2}\right)$ is close to 0 , which indicates that the oil content of the cultivars corresponds to a change in the environmental conditions. Such cultivars are demanding for a high level of agricultural technology, as only under this condition they will give the maximum return. Among the studied cultivars, VNIIMK 620, Lirina, and Karabalyksky 7 could be referred to them. The smallest variation interval of the oil content was shown by the cultivar Karabalyksky 7 for all years of the study.

Valuable cultivars are the ones that are characterized by a sufficiently high oil content and responsiveness to the growing conditions $(\mathrm{bi} \geq 1)$ and at the same time have low stability, which indicates a progressive increase in the oil content of seeds with improved growing conditions. This reaction is peculiar to the cultivars of an intense type. This group includes the cultivars Severny, Biryuza, Kazar, and Ilyich.

The third group includes those cultivars that have a relatively low average oil content, characterized by a weak response to improved environmental conditions (bi $\leq 1)$ and high stability, which is peculiar to the cultivars of an extensive type (Kostanay amber).

Table 2. Formation of oil content depending on the genotype and growing conditions

\begin{tabular}{|c|c|c|c|c|c|c|c|}
\hline \multirow[b]{2}{*}{ Cultivar } & \multicolumn{4}{|c|}{ Oil content, \% (reduced to dry matter) } & \multirow{2}{*}{$\begin{array}{c}\text { Variation } \\
\text { interval, max- } \\
\text { min }\end{array}$} & \multirow[b]{2}{*}{ Plasticity, bi } & \multirow[b]{2}{*}{ Stability, $\sigma_{\mathrm{d} 2}$} \\
\hline & 2015 & 2016 & 2017 & $\begin{array}{c}\text { average } \\
\text { for } 3 \text { years }\end{array}$ & & & \\
\hline Severny & 45.9 & 42.9 & 43.4 & 44.1 & 2.5 & 2.84 & 0.49 \\
\hline Isilkulsky & 46.5 & 42.8 & 42.1 & 43.8 & 4.4 & 3.52 & 0.04 \\
\hline Biryuza & 48.8 & 45.2 & 44.8 & 46.3 & 4.0 & 3.53 & 1.21 \\
\hline VNIIMK 620 & 48.2 & 46.5 & 46.4 & 47.0 & 1.8 & 2.51 & 0.01 \\
\hline Lirina & 47.5 & 45.5 & 46.0 & 46.3 & 1.5 & 2.44 & 0.04 \\
\hline Karabalyksky 7 & 47.3 & 46.8 & 47.4 & 47.2 & 0.5 & 1.72 & 0.04 \\
\hline Kazar & 44.9 & 43.3 & 42.6 & 43.6 & 2.3 & 2.50 & 0.09 \\
\hline Kostanay amber & 44.1 & 43.6 & 42.4 & 43.4 & 1.7 & 2.11 & 1.44 \\
\hline Ilyich & 43.7 & 42.7 & 41.4 & 42.6 & 1.7 & 2.35 & 0.09 \\
\hline Average for cultivars & 46.3 & 44.4 & 44.1 & 44.9 & 2.2 & & \\
\hline Variation interval, max-min & 5.1 & 3.2 & 4.7 & 4.6 & & & \\
\hline
\end{tabular}




\section{CONCLUSIONS}

Fat biosynthesis in oil flax seeds depends on the genotype and climatic conditions of cultivation. The interval of variation from growing conditions is $2.2 \%$ on average, which is 2.1 less than that from the influence of the genotype. The cultivars VNIIMK 620, Lirina and Karabalyksky 7 in the dry steppe zone should be classified as highly demanding for agricultural technology to obtain the maximum oil content, while the cultivars Severny, Biryuza Kazar and Ilyich - as extensive cultivars providing a progressive increase in the oil content with improved growing conditions. The optimum accumulation of fat in seeds is ensured by the sum of active temperatures during the ripening period $-350-400^{\circ} \mathrm{C}$, which should be taken into account in determining the timing of sowing flax under specific soil and climatic conditions.

\section{REFERENCES}

1. Andruszczak S., Gawlik-Dziki U., Kraska P. 2015. Yield and quality traits of two linseed (Linum usitatissimum L.) cultivars as affected by some agronomic factors. Plant soil and environment, 61, 247-252.

2. Antonova O.I., Gerlets E.A. 2012. Effect of oil flax foliar dressing on seeds yield and quality in various fertilized backgrounds in temperate-arid and forest-outlier steppe. Bulletin of Altai State Agricultural University, 12(98), 5-8.

3. Brazhnikov V.N. 2004. Agroecological evaluation of flax and methods of its cultivation in the conditions of the Middle Volga region. Doctoral dissertation. The author's summary, Penza.

4. Brazhnikov V.N., Brazhnikova O.F. 2013. Results of oil flax selection. Proceedings of the scientific and practical conference "Scientific and Practical Aspects of Technologies for Cultivation and Processing of Oil Crops". Ryazan: FSBEE HPE RSATU, 50-53.

5. Bushnev A.S., Mamyrko Yu.V., Podlesny S.P. 2009. Productivity of oil flax varieties depending on cultivation conditions (crop rotation, method of soil treatment) on leached chernozem of Northern Precaucasus. Oil crops. Scientific and Technical Bulletin of All-Russian Research Institute of Oil Crops, 1(140), 15-22.

6. Cherenkov O.A. 2009. Formation of the productivity of oil flax under the influence of fertilizers against the background of herbicides during sowing at different times on dark chestnut soils. Doctoral dissertation. The author's summary, Barnaul.

7. Galitsky D.N., Shamanin V.P. 2014. The dependence of accumulation of oil and fatty acid composition of environmental conditions in the seeds of flax oil in southern forest-steppe zone of Omsk region. Omsk Scientific Bulletin, 2(134), 160-173.

8. Galkin F.M., Sorochinskaya M.A. 1984. Interrelation of properties in oil flax hybrids F1. Bulletin of VNIIMK Scientific and Technical Information, $86,15-17$.

9. Gringof I.G., Pasechnyuk A.D. 2005. Agrometeorology and agrometeorological observations, Saint Petersburg.

10. Krasnova D.A. 2010. Selection value of oil flax samples in forest-steppe conditions of the Middle Volga region. Doctoral dissertation. The author's summary, Kazan.

11. Kumar S., You F.M., Duguid S. et al. 2015. QTL for fatty acid composition and yield in linseed (Linum usitatissimum L.). Theoretical and applied genetics, 128(5), 965-984.

12. Kuznetsova G.N. 2004. Optimization of oil flax mineral nutrition in the Southern forest-steppe of Western Siberia. Doctoral dissertation. The author's summary, Omsk.

13. Magomedov K.G., Khaniev M.Kh., Khanieva I.M., Shamurzayev R.I. 2008. The main elements of oil flax cultivation technology in the KabardinoBalkar Republic. Fundamental Research, 5, 4.

14. Malysheva A.G., Sorochinskaya M.A. 1981. Biochemical features of seeds of oil flaxseed varieties. Bulletin of VNIIMK Scientific and Technical Information, 78, 31-33.

15. Ryzheeva O.I. 1969. Oil flax selection for oil fatty acid composition. Bulletin of VNIIMK Scientific and Technical Information, 54-58.

16. Safonov M.D. 1952. Oil flax selection and seedgrowing. Scientific report of the Voronezh Experimental Station of Oil Crops. Voronezh Regional Book Publishing, 116-145.

17. Worku N., Heslop-Harrison J.S., Adugna W. 2015. Diversity in 198 Ethiopian linseed (Linum usitatissimum) accessions based on morphological characterization and seed oil characteristics. Genetic resources and crop, 62, 1037-1053.

18. Zoidze E.K. 2004. One approach to investigation of unfavorable agroclimatic events under conditions of climate change in the Russian federation. Meteorology and Hydrology, 1.

19. Zuk M, Richter D, Matula J, Szopa J. 2015. Linseed, the multi-purpose plant. Industrial Crops And Products, 75, 165-177. 